JPH: Jurnal Pembaharuan Hukum

Volume 8, Number 1, April 2021

\title{
THE MARRIAGE, DOCUMENTS AND DIVORCE IN TURKEY
}

\author{
Ebuzer Ersoy \\ Civil Matter Istanbul, Turkey \\ ebuzer ersoy@hotmail.com
}

\begin{abstract}
Turkish law is applied for all marriage procedures of asylum-seekers, refugees and stateless persons to be conducted in Turkey. Under Turkish law, a Turkish national and an asylum-seeker, refugee or stateless person, or two asylum-seekers or refugees of different nationalities, can be married by the Turkish authorities. All marriages carried out by the Turkish authorities are subject to the Turkish Civil Code and related regulations. Marriages are conducted by marriage officers at the Marriage Departments of municipalities. Couples intending to marry therefore need to submit the relevant documents to municipalities. Please see the section below on the required documents. It is important to note that only official (civil) marriages are legally recognized in Turkey, as defined under the Turkish Civil Code. Other forms of marriage, without an official marriage, are not recognized in Turkey. Getting an official marriage is important as it will secure and guarantee the legal rights of children and of spouses, especially women. Only after the official marriage is a religious marriage (carried out by imams) permitted.
\end{abstract}

Keywords: Marriage; Divorce, Law; Procedures.

\section{A. INTRODUCTION}

According to the Civil Law in Turkey, future spouses have the right to protect their assets with the help of a prenup signed in the country, before the marriage ${ }^{1}$. This kind of pre-nuptial agreement is settled at a public notary and comprises the marital property regime, according to the Civil Code and especially Article 242. In other words, a prenup will comprise information about the assets of spouses and the division of property in case of a separation or divorce. All the legal aspects of a pre-nuptial agreement can be discussed entirely with one of our lawyers in Turkey ${ }^{2}$.

A marriage can be annulled if one of the spouses has been forced to get married, or the rights have been seriously violated. If one of the spouses lived outside Turkey for more than a year, the other one can solicit the annulment of marriage. Violence and abuse in a marriage are serious grounds to terminate a

1 Alper, Ö. M. Erengin, H. Manguoğlu, A. E. Bilgen, T. Cetin, Z. Dedeoğlu, N. , and Lüleci, G., 2004, Consanguineous Marriages in the Province of Antalya, Turkey, Annales de Génétique 47, page.129-38;

2 Baykara-Krumme, H., 2013, Understanding Transnational Partner Choice: A Country-of-Origin Perspective on Marriage Migration From Turkey to Europe. Presentation at the Norface Migration Conference on Migration: Global Development, New Frontiers, University College London; 
marriage in Turkey. If you believe you are found in this difficult position, you should request the legal advice and support of a Turkish lawyer. He/she can represent you with a power of attorney if you want to cancel the marriage. Feel free to address your inquiries to our specialists and be helped by a team of professionals ${ }^{3}$.

\section{B. RESEARCH METHODS}

Method The research approach used in this writing is to use a descriptive analysis approach, namely a method by describing or describing the facts that occur in society about which then analyzes juridical normative, namely by searching for and finding positive legal aspects in accordance with the problem under study in order to be determined to solve a particular legal problem, in the form of positive law and how it is implemented ${ }^{4}$.

\section{RESULT AND DISCUSSION}

\section{Legal Age Of Marriage In Turkey}

There are only a few exceptions that allow someone to marry before turning 18. A 17-year-old person may be granted permission to be married with the consent of his/her parents or legal guardian; and a 16-year-old person may be granted permission to be married by a court decision and with the consent of his/her parents or legal guardian ${ }^{5}$.

\section{Legal Sanctions For Under-Age Marriage}

An unofficial 'marriage' with a child is considered as child abuse under the Turkish Penal Code. Perpetrators are punished, including with prison sentences ${ }^{6}$. State institutions, health and education institutions, as well as NGOs are obliged to inform the Turkish authorities about a child facing any kind of protection risk. Additionally, anyone who is aware of a crime being committed is obliged to inform the authorities ${ }^{7}$.

You can find out more about the negative effects of child marriage, as well as information on how you can seek protection and assistance, by

3 Baykara-Krumme, H. , and Fuß, D, 2009, Marital Migration to Germany: Determinants of Transnational Partner Selection by Turkish-Origin Migrants"/"Heiratsmigration Nach Deutschland: Determinanten der Transnationalen Partnerwahl Türkeistämmiger Migranten, Comparative Population Studies/Zeitschrif für Bevölkerungswissenschaft 34, page. 135-64.

4 Guveli, A. Ganzeboom, H. Baykara-Krumme, H. Platt, L. Eroğlu, S. Spierings, N. Bayrakdar, S. Bauck, B. , and Sozeri, E. 20142000 Families: Identifying the Research Potential of an Origins-of Migration Study. Discussion Paper No. 2014-7. Norface Research Programme on Migration, Department of Economics, University College London;

5 Davidoff, L. 2005, Kinship as a Categorical Concept: A Case Study of Nineteenth Century English Siblings, Journal of Social History 39, page. 411-28.

6 https://help.unhcr.org/turkey/social-economic-and-civil-matters/marriage-and-divorce/ accessed on March 9, 2021

7 Bras, H. van Poppel, F. , and Mandemakers, K., 2009, Relatives as Spouses: Preferences and Opportunities for Kin Marriage in a Western Society. American Journal of Human Biology 21, page.793-804. 
reading our leaflet on child marriages, forced marriages and domestic violence. In addition to the age requirements, the Turkish Civil Code specifies other conditions that couples have to meet in order to marry. Only those who have the mental capacity to make decisions are allowed to marry; mental illness is a barrier to marriage. Marriage between close relatives is prohibited. This includes marriages between siblings; marriages between uncles, aunts and their nephews and nieces; marriages between a parent and his/her adopted child, as well as between a parent and the children or former spouse of his/her adopted child; and marriages between a person and the immediate family member of a former spouse ${ }^{8}$.

If one or both of the individuals wishing to marry have already been married, that previous marriage must first be terminated. Under the Turkish Civil Code, polygamy is not allowed and considered a crime; this regulation applies to Turkish nationals as well as foreigners, including refugees. Formerly married woman cannot ordinarily marry again until 300 days after the date on which the previous marriage was terminated. However, if the woman obtains a medical report indicating that she is not pregnant, the 300-day waiting period is not required.

\section{Documents Required In Order To Marry}

In order to get married, the documents below need to be submitted to the Marriage Departments of the municipalities:

a. Petition of the marriage: the couple must file a petition of marriage (evlenme beyannamesi in Turkish), signed by both individuals applying to marry;

b. Celibacy document certifying that the applicants are not already married;

c. Medical report confirming that the applicants are free from diseases that would prevent them from getting married;

d. International protection applicant registration document; international protection applicant identity document; international protection status holder identity document; or temporary protection identity document;

Additionally, the written consent of a legal representative, including a certified signature, is required for the marriage of minors and of persons with limited capacity 9 .

\section{Consular Marriage}

Art. 12 of the Marriage Regulation, in addition to the Civil Registration Services Act, clearly states that two non-Turkish citizens can get married in Turkey by an authorized marriage officer. While Turkish officers are solely authorized, there is also a choice for two non-Turkish citizens that are citizens of the same country. Accordingly, if their national law permits and if their country of citizenship approves, two non-Turkish

8 Charsley, K. 2012, Transnational Marriage. New Perspectives From Europe and Beyond. New York, NY: Routledge;

9 Cherlin, A. J. 2012, Goode's World Revolution and Family Patterns: A Reconsideration at Fifty Years, Population and Development Review 38, Page.577-607. 
citizens can get married in the Turkish missions of their country of citizenship. Widely known as "consular marriage", this right is not recognized for refugees and stateless people, who can only get married by a Turkish marriage officer. At this point, it is important to recognize that the "two non-Turkish citizens that are citizens of the same country" stipulation can be changed by treaties and agreements ${ }^{10}$.

Italy is currently the only country that has a treaty with Turkey on this issue, and both countries permit their citizens to get married with a citizen of a third country in their missions in Italy and Turkey. It is possible for a foreign citizen living in Turkey to marry a Turkish citizen provided that the former has been living here based on a residence or work permit. An important thing to notice is that each Turkish city has its own Civil Marriage Registration Office, so the requirements related to the documents which need to be presented by both spouses may differ. Another important aspect to consider is that the foreign citizen must have a valid residence or work permit upon filing the application for getting married in Turkey. If this requirement is not met, the marriage cannot be registered ${ }^{11}$.

Also, the foreign citizen will be required to file certain documents which need to be translated in Turkish and apostilled. If in the case of the foreign national, the document requirements are the ones mentioned above, the foreign citizen must present the following with the Marriage Registration Office:

a. 4 passport-size recent photographs (it is possible for 6 pictures to be required in certain cases);

b. the foreign citizen's passport in original and copy (a translated copy can be requested);

c. the foreign citizen's residence permit in original, but a copy is also necessary in certain cases;

d. the foreign citizen's birth certificate which needs to be translated into Turkish;

e. the notarized permit to get married issued by the Embassy or Consulate in Turkey;

f. the translated and notarized divorce certificate (where available) and the healthcare certificate.

The Family Law in Turkey protects not only the idea of family and children but also provides information about the rights a family has in this country. In the case of a divorce, the custody will enter the discussion, if minor children are involved. We remind that according to the Civil Code Law No. 4721, both parents are in charge of the good education of the child until he/she is 18 years of age. Children in Turkey have many rights, and parents

10 Ghimire, D. J. Axinn, W. G. Yabiku, S. T. , and Thronton, A. 2006, Social Change, Premarital Nonfamily Experience, and Spouse Choice in an Arranged Marriage Society, American Journal of Sociology 111, page.1181-218.

11 https://www.lawyer-turkey.com/marriage-in-turkey accessed on March 9, 2021 
must act in the best interest. If one of the parents obtains the custody, the other one will have to pay the alimony and sustain education and correct living conditions ${ }^{12}$.

The same Family Law in Turkey provides information about the annulment of a marriage in this country, plus details about pre- and postnuptial agreements that refer to the properties of future spouses. If you believe you need more details about marriage in Turkey and Family Law, please feel free to get in touch with our Turkish lawyers.

\section{Conditions For Foreigners Getting Married In Turkey}

A foreigner who wants to get married in Turkey should know that only civil marriages are legally recognized. Additionally, any foreign or local citizen can have a religious ceremony only if he/she wants. A foreigner who is not legally allowed to marry in his country of residence can't marry either in Turkey. If two foreigners of the same nationality decide to get married in Turkey, they will go in front of the authorities from the embassy or consulate of their country in Turkey or in front of Turkish authorities who are entitled to perform civil marriages. If you choose the second option, you need firstly a proof that you are allowed to marry. You can obtain this document from the authorities in your country of residence or from the embassy of your country in Turkey. If the foreigners have two different nationalities, they must go to the Turkish authorities for marriage. The same procedure is settled also for marriages between a foreign citizen and a Turkish citizen.

\section{Conditions For Getting Married In Turkey}

Every citizen who wants to get married in Turkey, in front of the Turkish authorities or the officials from the embassy, must observe the following conditions:

a. to be 19 years old or older; if one of the future spouses is younger, he/she needs special consent from his/her parents;

b. is not mentally ill;

c. is not close relatives to his/her future spouses;

d. if he/she was married before in any other country, then it is necessary to present a proof of divorce or marriage dissolution.

The citizens who want to get married in Turkey need a few documents, such as a petition, a certificate of celibacy proving he/she is eligible to marry, identification papers, photos of the two future spouses, health certificate.

There are also a few regulations for marring in Turkey. The two future spouses must be woman and man and the Turkish women, who have divorced before, must wait 300 days until they will marry again. Another country preferred by Turkish citizens for getting married is UAE with its

12 Givens, B. P. , and Hirschman, C. 1994, Modernization and Consanguineous Marriage in Iran, Journal of Marriage and Family 56, page. 820-34 
famous Dubai where more and more ceremonies take place every year. For marriage in UAE, there are other conditions to observe ${ }^{13}$.

\section{Getting Married As Foreign Citizens In Turkey}

As mentioned earlier, foreign citizens are allowed to register their marriages to another foreigner or Turkish citizen in Turkey. Foreigners interested in registering their marriages in Turkey should know the following:

a. the civil registration of the marriage is the only legally recognized by the authorities;

b. foreign citizens are recommended to arrive a few days earlier before the ceremony takes place;

c. the presence of a sworn translator must be present in the case of two foreigners getting married and who do not speak Turkish;

d. if the foreign citizens also want to organize a religious marriage, this can only take place after the civil registration of the marriage.

The marriage of two foreign citizens in Turkey will be recognized in other countries. With respect to the documents which need to be provided, our Turkish lawyers can offer detailed information based on the foreigners' country of origin ${ }^{14}$.

It is important to know that the marriage registration documents must be filed by both future spouses, as they also need to fill out an application form. This requirement is necessary no matter the citizenship of the spouses. This is why it is important for foreigners interested in getting married in Turkey to arrive a few days earlier. It should also be noted that two witnesses are required to attend the ceremony. In the case of Turkish citizens, these cannot be family members, however, family friends are accepted.

\section{Foreign Citizens Marrying A Turkish National}

As a contract of Family Law, marriage has strictly regulated formal requirements under the Turkish Civil Code (hereinafter referred to as "TCC"). Therefore, the validity of a marriage depends not only on the parties' capacities to marry or the absence of an impeding situation, but also on complete consistence with these strict formal requirements ${ }^{15}$.

Regarding the formal requirements for marriage, TCC refers to the Marriage Regulation and the Law on the Civil Registration Services No.5940. Requirements for non-Turkish citizens are therefore deducted by joint consideration of these two legal texts. Upon first look, it is clearly understood that identification of the authorized office which will host the marriage is of foremost consideration. According to the Law on the Civil

13 Glick, J. E. 2010, Connecting Complex Processes: A Decade of Research on Immigrant Families, Journal of Marriage and Family 72, page.498-515.

14 Francesco Dagnino, Partner of Lexia Avvocati, BridgeWest takes great care of selecting its affiliates worldwide and Turkey is no exception.

15 Ibid. 
Registration Services Art. 22(2), "the marriage officer is the mayor or officers that will be appointed by the mayor in places where there is a municipality, and the headman in villages and rural areas.". The same Article also states on its final paragraph that when one of the spouses is a non-Turkish citizen, the authorized office is "mayoral marriage officers or heads of registry offices", and therefore forbids the headmen and muftis who are authorized for marriage between two Turkish citizens ${ }^{16}$.

\section{Divorce}

It is possible to get a divorce in Turkey, even if the marriage was conducted outside of Turkey. Turkish legislation is the applicable law when it comes to the divorce procedures of asylum-seekers, refugees and stateless persons. Asylum-seekers, refugees and stateless persons wishing to divorce in Turkey are subject to the provisions of the Turkish civil Code.

The civil status of asylum-seekers, refugees and stateless persons acquired in the country of origin or former habitual residence in line with the rules of the respective country is recognized in Turkey. In some countries, religious marriages are recognized as official marriages. Therefore, the religious marriage conducted in the country of origin or former habitual residence would also be recognized in Turkey, as this is a form of official marriage in that country. Other traditional forms of marriage, as long as the person had testified so during registration with the PDMM, would also be recognized in Turkey, even if an official document certifying the marriage could not be submitted at the time of registration.

The Procedures for divorce and custody, to get divorced, you must submit a divorce petition to the relevant Family Court. In the divorce petition, you may request from the court settling of the custody issue(s) with respect to your children. Refugees may receive legal assistance through the Legal Aid Bureaus of the Bar Associations for divorce and custody procedures. Upon request, a lawyer may be appointed free of charge by the Bar Association if it is assessed that he/she does not have the financial means to cover attorney and judicial fees.

The Turkish Family Law provides for various rights and obligations for the citizens of this country, but also for foreigners relocating here. Among the rights, are getting married and getting divorced in Turkey. A marriage can be concluded by Turkish citizens, by foreign citizens living in Turkey, but also by a Turkish and a foreign citizen.

The conditions imposed for the three types of marriage registration procedures are slightly different in terms of documentation and can be explained by our lawyers in Turkey. We also offer other legal services related to the Family Law; however, we can also assist those interested in setting up a business in Turkey, for example.

16 https://www.mondaq.com/turkey/family-law/992010/marriage-in-turkey-for-non-turkish-citizens accessed on March 9, 2021 


\section{CONCLUSION}

The municipal authority or the local marriage registrar in Turkey can conduct a civil wedding ceremony, in the presence of a census office with legal validity. We remind you that a religious ceremony in Turkey cannot take place without the civil one. Moreover, if you intend to get married in Turkey, it is required to enter the country within a few days prior to the ceremony, to take care of all the necessary documents for the marriage. The paperwork and the formalities are not complex but it might take some time if you are a foreigner intending to get married in Turkey. This is where you can rely on the legal support of our law firm in Turkey and request assistance prior to your arrival in this country. This way you can be sure that all the formalities are handled in a correct manner before the ceremony takes place. It is important to note that future spouses must prepare a set of medical tests as part of the needed documents for marriage.

\section{Books:}

\section{BIBLIOGRAPHY}

Alper, Ö. M. Erengin, H. Manguoğlu, A. E. Bilgen, T. Cetin, Z. Dedeoğlu, N. , and Lüleci, G., 2004, Consanguineous Marriages in the Province of Antalya, Turkey." Annales de Génétique;

Baykara-Krumme, H. , and Fuß, D., 2009, Marital Migration to Germany: Determinants of Transnational Partner Selection by Turkish-Origin Migrants"/"Heiratsmigration Nach Deutschland, Determinanten der Transnationalen Partnerwahl Türkeistämmiger Migranten, Comparative Population Studies/Zeitschrif für Bevölkerungswissenschaft;

Baykara-Krumme, H., 2013, Understanding Transnational Partner Choice: A Country-of-Origin Perspective on Marriage Migration From Turkey to Europe, Presentation at the Norface Migration Conference on Migration: Global Development, New Frontiers, University College London;

Charsley, K., 2012, Transnational Marriage. New Perspectives From Europe and Beyond, New York, Routledge;

Cherlin, A. J., 2012, Goode's World Revolution and Family Patterns: $A$ Reconsideration at Fifty Years, Population and Development Review;

Francesco Dagnino, Partner of Lexia Avvocati, BridgeWest takes great care of selecting its affiliates worldwide and Turkey is no exception;

Guveli, A. Ganzeboom, H. Baykara-Krumme, H. Platt, L. Eroğlu, S. Spierings, N. Bayrakdar, S. Bauck, B. , and Sozeri, E. 2014 2000, Families: 
Identifying the Research Potential of an Origins-of Migration Study. Discussion Paper No. 2014-7. Norface Research Programme on Migration, Department of Economics, University College London;

\section{Journals:}

Bras, H. van Poppel, F. , and Mandemakers, Relatives as Spouses: Preferences and Opportunities for Kin Marriage in a Western Society, American Journal of Human Biology 21, 2009;

Davidoff, L, Kinship as a Categorical Concept: A Case Study of Nineteenth Century English Siblings, Journal of Social History, 39, 2005;

Ghimire, D. J. Axinn, W. G. Yabiku, S. T. , and Thronton, A, Social Change, Premarital Nonfamily Experience, and Spouse Choice in an Arranged Marriage Society, American Journal of Sociology, 111, 2006;

Givens, B. P. , and Hirschman, C, Modernization and Consanguineous Marriage in Iran, Journal of Marriage and Family, 56, 1994;

Glick, J. E, Connecting Complex Processes: A Decade of Research on Immigrant Families, Journal of Marriage and Family, 72, 2010;

\section{Websites:}

https://help.unhcr.org/turkey/social-economic-and-civil-matters/marriage-anddivorce/ accessed on March 9, 2021

https://www.lawyer-turkey.com/marriage-in-turkey accessed on March 9, 2021

https://www.mondaq.com/turkey/family-law/992010/marriage-in-turkey-for-nonturkish-citizens accessed on March 9, 2021 